\title{
COMMENTARY
}

\section{PHILIPPINE-CHINA RELATIONS, TERRITORIAL DISPUTES AND THREATS TO ASEAN STABILITY}

\author{
Jeconiah Louis Dreisbach ${ }^{a}$
}

\begin{abstract}
This commentary deliberates on the role and actions of the Philippine Government over the possible threat to the stability of the Southeast Asian region potentially brought about by long-running territorial disputes between ASEAN member states and China, among others. The ASEAN principle of non-interference is being questioned for being a hindrance to the resolution of these disputes. In addition, ground accounts from citizens of Southeast Asian countries present dissatisfaction over relations of their governments with China, whereby joint ventures and partnerships in development projects with the latter are continuously criticized, with several South Asian and Pacific Island nations having already fallen into the so-called "Chinese debt-trap". Filipinos have raised the argument for these disputes to be collectively resolved under the United Nations and ASEAN dispute settlement mechanisms as China seems to have neither complied, nor respected the decision made by the Permanent Court of Arbitration over the West Philippine Sea claims in July 2016, which favoured the Philippines.
\end{abstract}

Keywords: Philippines, ASEAN, Chinese debt trap, West Philippine Sea, territorial dispute

\section{INTRODUCTION}

\section{"Vietnam. Philippines. Friends."}

Those were the words that Vietnamese fisherman uttered when they saved 22 Filipino fishermen from an alleged ramming by a Chinese vessel in Reed Bank (on $9^{\text {th }}$ June, 2019) (Lasco, 2019), a guyot on the West Philippine Sea which the People's Republic of China claims to be part of her territory. This geographic feature is part of the Spratly Islands archipelago that was claimed by the Philippines and adjudged and resolved by the Permanent Court of Arbitration in 2016 to be part of the country's Exclusive Economic Zone (EEZ). The dispute however, is not just between these two countries, as the NineDash Line - a body of water with an area of 3.5 million square kilometers claimed by China, also consists of territories claimed by Brunei, Indonesia, Malaysia, Vietnam, and Taiwan (Gao \& Jia, 2013).

\footnotetext{
a Corresponding Author: Jeconiah Louis Dreisbach is a Senior Research Specialist at the Asian Institute of Management and Fellow of the Royal Asiatic Society of Great Britain and Ireland. Email: jeconiah_dreisbach@dlsu.edu.ph
} 
During the Association of Southeast Asian Nations (ASEAN) Summit held in the Philippines in 2017, the country's President Rodrigo Duterte had called upon member states of the regional organization to renew their commitment in respecting the principles of the 1976 Treaty of Amity and Cooperation, which include the policy of noninterference among states to promote stability and peace in Southeast Asia (Delizo, 2017). His assertion on having an independent and non-interfering foreign policy has repeatedly been ${ }^{\mathrm{b}}$ criticized by nationalist groups fighting for the West Philippine Sea territories as having 'double standards' (Lasco, 2018) which discourses opine to be proChinese as he prefers to engage in bilateral negotiations with the Chinese Government (Parrocha, 2019), instead of engaging in multilateral talks that will involve a third nonmutual country.

Duterte dismissed the case as a 'little maritime accident' with his Agriculture Secretary stating that the 'simple issue has blown out of proportion' (ABSCBN News, 2019). In addition, Malacañan Palace, the seat of government, doubted the statements made by the Filipino fishermen (Romero, 2019) and stated that, as lawyers, they were 'waiting for the facts' of the case (Viray, 2019). As the Chinese Embassy (2019) issued their official statement over the incident, Duterte stood by the information provided by Beijing and doubted the accounts of his fellow Filipinos. The statements by the commander-in-chief had disheartened the captain of the fishing vessel, especially when the Vietnamese fishermen who saved the Filipinos had confirmed the incident. Duterte also referred to the body of water where the fishermen were allegedly rammed as the 'China Sea' (Calonzo, 2019).

Philippine Supreme Court Senior Associate Justice Antonio Carpio, one of the lawyers who championed the arbitration case between the Philippines and China ${ }^{1}$ had berated the President for questioning the legal ownership of the islands. He said,

"Don't say that, because the tribunal has already ruled with finality. There's no appeal. We're the owners of the resources there. There is no legal dispute as to the ownership of oil, fish, and gas. It belongs exclusively to the Philippines. The only problem is how to get China to comply" (ABSCBN News, 2018).

As such, the area should be called the West Philippine Sea, and not South China Sea.

The pronouncement of an independent foreign policy may be a direct practice of the principle of non-interference, but five ASEAN member states are involved in territorial disputes over the so-called South China Sea. The principle, as codified in the ASEAN Charter (2019), ensures "the respect for the independence, sovereignty, equality, territorial integrity and national sovereignty of all ASEAN Member States" and nonintervention on domestic issues of state-members (ASEAN Charter, 2019, p. 6). Earlier on the Charter, it is mentioned that the primary purpose of the regional organization is "to 
maintain and enhance peace, security and stability" in the region (ASEAN Charter, 2019, p. 3).

Much has been written on this principle and its supposed role in the security cooperation of member states in the region, especially on issues pertaining to territorial disputes (Amer, 2012; Heng, 2014; Corthay; 2016; Hernandez, 2016; and Terada, 2017). This principle has faced several challenges since 1997. Out of the nine issues and proposals that questioned the continued proliferation of the principle, the Philippines advocated for the deviation from the non-interference principle six times (Nguyen, 2016). However, during Duterte's administration, for the first time, the Philippines took a nonaggressive stand against Chinese intrusion into the area. So much so, that when the country hosted the ASEAN Summit in 2017, discussions on the dispute were said to be 'toned down' (Ono, 2017).

\section{REACTIONS OF ASEAN MEMBER STATES AGAINST CHINESE ACTIONS}

Unlike the Philippines, its neighboring countries took principled actions in the operations of the Chinese government in the disputed area. Indonesia established a military base containing more than 1,000 personnel in the Natuna Besar Island of the Riau archipelago, an area close to islands claimed by China (Kyodo News, 2018). Two years before that, the Indonesian Navy had shot and seized a Chinese boat fishing in the said area. Major Budi Amin - the Navy Western Fleet Command spokesperson, emphasized, "this arrest was made to show the world that Indonesia will take firm action against ships that violate our territory" (Associated Press, 2016).

Vietnam, with its longstanding history of conflict and triumph against China, is still not bowing down to the "Middle Kingdom." In 2014, a Chinese ship rammed a Vietnamese vessel fishing along the Paracel Islands, an area claimed by both countries (Nguyen, 2019). Following this incident, the Vietnamese government filed an official diplomatic protest against Beijing, stating that the Chinese ship had 'violated Vietnam's sovereignty over the Hoang Sa (Paracel) archipelago, threatened the lives and damaged the properties and the legitimate interests of Vietnamese fishermen" (Reuters, 2019).

ASEAN's fundamental principle on collective resolution-making among its member states continues to be a challenging feat. China's establishment of the Asian Infrastructure Investment Bank (AIIB) is already a significant competitor of the already developed and established regional and international investment banks such as the Asian Development Bank (ADB), World Bank (WB), and the International Monetary Fund (IMF). Kipgen (2018) alleges that China's influence over Cambodia and Laos, through their bilateral economic relations and projects, is silencing the latter countries. Enticing the Laotian government of economic progress for its people, they agreed to partner with China in its Belt and Road Initiative by letting the country build a high-speed train network that will connect peninsular Southeast Asia to Northeast Asia (Westerman, 2019). Once gloomy, the coastal city of Sihanoukville in Cambodia has been splurged with foreign Chinese investment (Ellis-Petersen, 2018). Today, sprawling skyscrapers have sprouted all over the provincial town. 


\section{DISHEARTENING GRASSROOTS SENTIMENTS}

These recent partnerships with the Asian hegemon have left Cambodian and Laotian citizens feeling powerless. "The Chinese have money, much more money than the Cambodians, and that means they have the power here now," said Cambodian shop owner Srey Mach in an interview with the South China Morning Post (Westerman, 2019). A local Laotian man also commented on the rail network being built across the country and said,

"I worry that when the trains are completed, there will be many, many Chinese [moving] in from China to live in Laos and they will take the job[s] from local people. All the money go back to China, not for Laos people" (Ellis-Petersen, 2018).

Filipinos have echoed the same sentiments. A local resident in the country's capital city Manila noticed the sudden flood of Mainland Chinese immigrants in the locality. He said, "the Chinese have invaded our islands in the West Philippine Sea, and now they're in my condo [building]. It's a home invasion" (Robles, 2018). A national survey on the perspective of Filipinos on the territorial dispute between the country and China revealed that $84 \%$ of the respondents are dissatisfied with the inaction of the Philippine Government on the reports that the Chinese military have built infrastructures on the islands that are under the country's sovereignty (De Vera-Ruiz, 2018).

Debt bombs are looming in this economic and financial partnership between China and some of the ASEAN states. Direct manifestations of the former taking advantage of high interest loans are the inability of nearby countries in the region to pay for such development projects and, in turn, surrendering them to China. As an example, the Sri Lankan government surrendered the strategic maritime port of Hambantota to Chinese firms for a 99-year lease as the country is unable to pay the US\$ 8 billion loan it took from China (Schulz, 2017). Meanwhile, the current Finance Ministry of the Maldives is having difficulties in providing a concrete figure for the loans that former president Abdulla Yameen took during his stint. As of this point in writing, data from the said Ministry shows that the country owes a total of US\$1,535 billion, or more than a quarter of Maldives' gross domestic product (GDP) (Munde \& Hill, 2019). In the Pacific, Tonga owes China US\$160 million, a third of its GDP, and Fiji is currently indebted with US\$500 million, or a tenth of the country's GDP (Mantesso, 2018).

Malaysian Prime Minister Tun Dr. Mahathir bin Mohamad admitted that his country would not be able to pay for the US\$20 billion rail link loan with China if they continued with the said venture (Jaipragas, 2019). In his state visit in Manila, the Prime Minister also warned Duterte of the possible debt trap that the latter went into for his primary infrastructure project, the 'Build, Build, Build' Programme (Venzon, 2019). The 
ADB President Nakao Takehiko, early on, already cautioned the Philippines and its member countries on the risks that come with borrowing finances from the Mainland Chinese Government (Bajo, 2018).

A contract of the Kaliwa Dam project, part of the 'Build, Build, Build' Programme, was exposed by a Filipino nationalist lawmaker in March 2019. In his exposé, it was revealed that Section 8.1 which covers "Waiver of Immunity" provides, "The Borrower (the Philippines) hereby irrevocably waives immunity on the grounds of sovereignty or otherwise for itself or its property" (Rivas, 2019). This ambiguous and unclear provision may threaten the sovereignty of the Philippines over its public properties and even its territories as we are unsure of how the Chinese legal system interprets this. The Duterte regime's spokesperson Salvador Panelo also raised an alarming statement in an interview, stating that there is "nothing wrong with using Philippines resources as collateral for (the) China loan" for he is certain that (the Philippines) falling into debt would never happen (CNN Philippines, 2019).

\section{IS COLLECTIVE REGIONAL DECISION-MAKING THE ANSWER?}

Comparing the financial situations of South Asian and Pacific Island countries, ASEAN member countries involved in loan transactions with the Chinese Government are still in their early stages and may still question the viability of these projects. However, the said countries are in complex situations due to the territorial disputes that they are embroiled in, as well as the independent dealings of former and current heads of government with China for their development plans.

Indonesia and Vietnam have been consistent in their stance against the intrusion of the Chinese military in their claimed territories. Malaysia, meanwhile, questions the ventures of former Prime Minister Najib Razak with Chinese firms. Despite winning the arbitration case against the People's Republic of China in 2016, the Duterte's regime had quickly brushed off the court's decision and chose to deal with the dispute over the West Philippine Sea bilaterally. On the other hand, Cambodia, Laos, and Myanmar are mum on their stance with regard to the issues that their neighboring countries are facing.

Going back to the words that Vietnamese fishermen uttered and the principle of non-interference, common folks' maritime linkages and experiences on the ground (and the sea) already suggest that regional stability is currently under threat due to the increasing military exercises and development carried out by the Chinese Government over the territories that are also claimed by ASEAN member states as being part of their sovereign territory and jurisdiction. Seventy-one per cent of Filipinos believe that this dispute should be brought upon the United Nations (UN) and ASEAN to ensure compliance by China, and that multilateral talks are necessary for the peaceful resolution of the said disputes (De Vera-Ruiz, 2018). Indeed, the pressure from the international community is crucial to awake China to its exploitations of economically weak states. 


\section{NOTES}

${ }^{1}$ The South China Sea Arbitration (The Republic of Philippines v. The People's Republic of China), Case Number 2013-19

\section{REFERENCES}

ABSCBN News. "Don't call West Philippine Sea 'disputed', says Carpio" (2018, March 18). Retrieved from https://news.abs-cbn.com/video/news/03/05/18/dont-call-westphilippine-sea-disputed-says-carpio.

ABSCBN News. "Simple maritime incident' at Recto bank 'blown out of proportion: Agri Chief" (2019, June 17). Retrieved from https://news.abscbn.com/news/06/17/19/simple-maritime-incident-at-recto-bank-blown-out-ofproportion-agri-chief.

Amer, R. "The South China Sea: Challenge for ASEAN" (2014, March), Institute for Security \& Development Policy Brief No. 150. Retrieved from https://www.files.ethz.ch/isn/185082/2014-amer-the-south-china-sea-challenge-forasean.pdf.

Associated Press. "Indonesian navy fires shots, seizes Chinese fishing boat near disputed South China Sea" (2016, May 30), South China Morning Post. Retrieved from https://www.scmp.com/news/asia/southeast-asia/article/1959643/indonesian-navyfires-shots-seizes-chinese-fishing-boat.

Association of Southeast Asian Nations. "The ASEAN Charter" (2012, May), ASEAN. Retrieved from https://asean.org/storage/2012/05/The-ASEAN-Charter-26thReprint.pdf.

Bajo, A. F. "ADB warns PHL, other countries on too much China loans" (2018, May 18) GMA News. Retrieved from https://www.gmanetwork.com/news/money/economy/652651/adb-warns-phl-othercountries-on-too-much-china-loans/story/.

Calonzo, A. "Duterte stands by China, doubts own fishermen in sea collision" (2019. June 17), Bloomberg. Retrieved from https://www.msn.com/en$\mathrm{ph} /$ news/national/duterte-stands-by-china-doubts-own-fishermen-in-sea-collision/arAAD3bfp?li=AAb280R.

CNN Philippines, "Panelo: Nothing wrong with using PH resources as China loan collateral" (2019, March 29), CNN. Retrieved from https://cnnphilippines.com/news/2019/3/25/Panelo-natural-resources-China-loancollateral.html?fbclid=IwAR1e_638DFJToD6mWkUv8vqmzc_Hv1JoJFnB0gIA7OkAb4FoK HTr_senwmM.

Corthay, E. (2016), The ASEAN doctrine of non-interference in light of the fundamental principle of non-intervention. Asian-Pacific Law \& Policy Journal, 17, 2, 1-14.

De Vera-Ruiz, E. "SWS: More Pinoys oppose government's policy of doing nothing vs. China's intrusion in WPS" (2018. Nov 20), Manila Bulletin. Retrieved from https://news.mb.com.ph/2018/11/20/sws-more-pinoys-oppose-governments-policyof-doing-nothing-vs-chinas-intrusion-in-wps/. 
Delizo, M. J. T. "Non-interference in ASEAN impossible, experts say" (2017, January 17), The Manila Times. Retrieved from https://www.manilatimes.net/noninterference-asean-impossible-experts-say/307352/.

Ellis-Petersen, H. "How Chinese money is changing Sihanoukville" (2018, July 31), South China Morning Post. Retrieved from https://www.scmp.com/magazines/postmagazine/long-reads/article/2158621/how-chinese-money-changing-sihanoukvilleno.

Embassy of the People Republic of China in the Philippines. "Chinese foreign ministry spokesperson's remarks on China-Filipino fishing vessels collision incident" (2019, June 20), Embassy of the People Republic of China in the Philippines. Retrieved from https://www.google.com/search?client=safari\&rls=en\&q=Chinese+foreign+ministry + spokesperson's+remarks+on+China-

Filipino+fishing+vessels+collision+incident $\&$ ie=UTF-8\&oe=UTF-8.

Gao, Z. \& Jia, B. B. (2013), The nine-dash line in the South China Sea: History, status, and implications. The American Journal of International Law, 107, 1, 98-124.

Heng, P. K. "The "ASEAN way" and regional security cooperation in the South China Sea" (2014, March), Robert Schuman Centre for Advanced Studies Global Governance Programme - EUI Working Papers 2014/121. Retrieved from http://cadmus.eui.eu/bitstream/handle/1814/33878/RSCAS_2014_121.pdf?sequence $=1 \&$ isAllowed $=\mathrm{y}$.

Hernandez, S. M. F. “The 'ASEAN way' and the South China Sea disputes: Institutional design and cooperation on regional security issues" (2016, July), Southeast Asia Research Centre Working Paper Series, College of Liberal Arts and Social sciences, City University of Hong Kong. Retrieved from http://www.cityu.edu.hk/searc/Resources/Paper/16071111_184\%20-\%20WP\%20$\%$ 20Sherlyn.pdf.

Jaipragas, B. "We just can't pay: Mahathir soothes China's ego over Malaysia's cancelled East Coast Rail Link" (2019, January 29), South China Morning Post. Retrieved from https://www.scmp.com/week-asia/geopolitics/article/2184073/wejust-cant-pay-mahathir-soothes-chinas-ego-over-cancelled.

Kipgen, N. (2018), ASEAN and China in the South China Sea Disputes. Asian Affairs, 49, 3, 433-448.

Kyodo News. "Indonesia opens military base near disputed South China Sea" (2018, December 19), ABS-CBN News. Retrieved from https://news.abscbn.com/overseas/12/19/18/indonesia-opens-military-base-near-disputed-southchina-sea.

Lasco, G. "Duterte's double standards" (2018, June 28), Philippine Daily Inquirer. Retrieved from https://opinion.inquirer.net/114229/dutertes-double-standards.

Lasco, G. (2019), "Vietnam. Philippines. Friends" (2019, June 20), Philippine Daily Inquirer. Retrieved from https://opinion.inquirer.net/122086/vietnam-philippinesfriends.

Mantesso, S. "Are China's cheap loans to poor nations a development boost or a debt trap?" (2018, Nov 15), ABC News. Retrieved from https://www.abc.net.au/news/2018-11-16/are-china-cheap-loans-to-poor-nations-a- 
Munde, S. \& Hille, K. "The Maldives counts the cost of its debts to China" (2019, February 10), Financial Times. Retrieved from https://www.ft.com/content/c8da1c8a-2a19-11e9-88a4-c32129756dd8.

Nguyen, D. "Vietnam displays fishing vessel sunk by Chinese in Paracel" (2019, May 29), VNExpress International. Retrieved from https://e.vnexpress.net/news/news/vietnam-displays-fishing-vessel-sunk-by-chinesein-paracel-3930897.html.

Nguyen, T-A. (2016), Norm or necessity? The non-interference principle in ASEAN. Cornell International Affairs Review, 9, 1, 1-31.

Ono, Y. "South China Sea dispute 'toned down' at ASEAN meeting" (2017, Nov 14), Nikkei Asian Review. Retrieved from https://asia.nikkei.com/Politics/South-ChinaSea-dispute-toned-down-at-ASEAN-meeting.

Parrocha, A. "PH, China open to resolve WPS 'irritants' through negotiations" (2019, April 29), Philippine News Agency. Retrieved from https://www.pna.gov.ph/articles/1068499.

Permanent Court of Arbitration. "The South China Sea Arbitration (The Republic of Philippines v. The People's Republic of China)" (2016, July 12), Permanent Court of Arbitration. Retrieved

from https://www.google.com/url?sa=t\&rct=j\&q=\&esrc=s\&source=web\&cd=3\&ved=2ah UKEwiDk4SejcPmAhWEYysKHatID74QFjACegQIAxAB\&url=https\%3A\%2F\%

Reuters. "Vietnam protests over China's sinking of vessel in contested South China Sea" (2019, March 22), South China Morning Post. Retrieved from https://www.scmp.com/news/asia/southeast-asia/article/3002794/vietnam-protestsover-chinas-sinking-vessel-contested.

Rivas, R. "Kaliwa Dam deal 'as onerous' as Chico River project" (2019, March 24), Rappler. Retrieved from https://www.rappler.com/business/226506-kaliwa-damcontract-onerous-chico-river-project.

Robles, R. 'Chinese workers 'flood' the Philippines, yet Duterte's officials 'don't know' how many there are" (2018, December 22), South China Morning Post. Retrieved from https://www.scmp.com/week-asia/economics/article/2178749/chinese-workersflood-philippines-yet-dutertes-officials-dont.

Romero, A. "Palace unsure of Filipino fishers' account on Recto Bank incident" (2019, June 18), The Philippine Star. Retrieved from https://www.philstar.com/headlines/2019/06/18/1927557/palace-unsure-filipinofishers-account-recto-bank-incident\#wwOSL56KxwlhhhU6.99.

Schulz, K. "Sri Lanka, struggling with debt, hands a major port to China" (2017, December 12), The New York Times. Retrieved from https://www.nytimes.com/2017/12/12/world/asia/sri-lanka-china-port.html.

Terada, T. "South China Sea dispute and institutional balancing: ASEAN, TPP and AIIB” (2017, May 23), International Studies Association International Conference 2017, Hong Kong. Retrieved http://web.isanet.org/Web/Conferences/HKU2017-s/Archive/253b3362-6522-494b8b8c-a4afa3b722e2.pdf. 
Venzon, C. "Mahathir warns Philippines about China loans" (2019, March 7), Nikkei Asian Review. Retrieved from https://asia.nikkei.com/Politics/Internationalrelations/Mahathir-warns-Philippines-about-China-loans

Viray, P. L. 'Palace: Duterte just 'waiting for facts' on Recto Bank collision" (2019, June 17), The Philippine Star. Retrieved from https://www.philstar.com/headlines/2019/06/17/1927235/palace-duterte-just-waitingfacts-recto-bank-collision\#CBDuJEQUoR8QB3j0.99.

Westerman, A. "In Laos, a Chinese-funded railway sparks hope for growth — And fears of debt" (2019, April 26), NPR. Retrieved from https://www.npr.org/2019/04/26/707091267/in-laos-a-chinese-funded-railwaysparks-hope-for-growth-and-fears-of-debt. 